\title{
Impact of Musical Creative Drama Education on Self-Confidence of Preschool Children
}

\author{
Serpil Umuzdaş ${ }^{1}$, Akanda Doğan ${ }^{2}$, Mehmet Serkan Umuzdaş ${ }^{3}$ \\ ${ }^{1}$ Assoc. Prof, Tokat Gaziosmanpasa University, State Conservatory, Tokat, Turkey \\ ${ }^{2}$ MS Student, Gaziosmanpasa University, State Conservatory, Tokat, Turkey \\ ${ }^{3}$ Assoc. Prof, Tokat Gaziosmanpasa University, State Conservatory, Tokat, Turkey \\ Correspondence: Serpil Umuzdaş, Assoc. Prof, Tokat Gaziosmanpasa University, State Conservatory, Tokat, Turkey.
}

Received: August 13, 2019

doi:10.11114/jets.v7i11.4471
Accepted: August 19, 2019 Online Published: August 22, 2019

URL: https://doi.org/10.11114/jets.v7i11.4471

\begin{abstract}
The aim of this study is to examine the impact of getting musical creative drama education on self-confidence of preschool children. The study was conducted in Tokat Private İlgim Schools, with 4, 5 and 6 year-old preschool children in the 2018-2019 academic year. The education was conducted with a total of 50 students, 29 being boys and 21 girls. The research data were collected through the Günalp self-confidence observation test that is applied to preschool children. At the end of the 10-week experimental period, the impact of creative drama education on self-confidence of preschool children was tested. SPSS program was used for data analysis. "ANOVA" was used in the comparison of the levels of self confidence by hometown, number of individuals living at the household, status of parents, number of siblings, child's birth order in the family, economic status of the family, age of starting school, caregivers before starting school, education level and occupation types. Results of the study showed that there was a significant difference in self-confidence development of preschool students as a result of creative drama studies. No statistically significant difference was found in the self-confidence development of students in terms of gender, hometown, number of individuals living at the household, status of parents, number of siblings, child's birth order in the family, economic status of the family, age of starting school, caregivers before starting school, education level and occupation types of parents. There was a significant difference between pre-school students' self-confidence in proportion to their ages. It was seen that musical creative drama activities make a positive impact on the self-confidence of preschool students.
\end{abstract}

Keywords: drama, self-confidence, music, child, preschool

\section{Introduction}

Game is a universal notion and the child can transform any space into a play environment. Even though the type of games and the tools used in games vary across the region, the game maintains its existence. It is understood that children whose game activities are restricted often have psychological problems. In early childhood, games are used as both a learning tool and entertainment (Koçyigit et al., 2007).

Game is an important activity in life, that is realized through interaction in social environment in the personality development process. Games integrate and develop skills and experiences at cognitive, emotional, and psycho-motor domains and improve children's imagination, provide language development, enhance interaction with themselves or other people (Bayram et al., 1999).

Some results point to the benefits of active play for promoting self-regulation and offer insight into possible interventions designed to promote self-regulation and academic achievement (Derek et al, 2014).

Gaming is the activity that the child spends most of his time during the play period between the ages of three and six. Playing games provides the environment in which the child develops his mental activities, feels himself free, uses his creativity and develops friendship bonds at the same time. In the games with several characters, children play themselves as well as other characters. Therefore, they also learn about social relations. Therefore, the friendship ties provided by games demonstrate the important need for love. Children who do not have the opportunity to interact in a play environment may be shy and insecure in future (Yörükoğlu, 1986).

The 4-6 years of age is a period in which creativity emerges in children. In this period, interest in instruments and 
painting starts in children. Playing with colored play dough, crayons and so on gives the child great pleasure. During this period, children may use some hard-grained foods such as rice and lentils as material in their games. The child puts these materials into containers and enjoys hearing the sounds coming out of those containers (Sütçü, 2006).

The idea of self is dominant throughout this period. Thinking of self does not necessarily mean that children show self-interest or excessive self-interest. They become inadequate in matters such as seeing anything in a way that other people see or paying attention to the emotions and needs of others (Güryıl, 2011).

Children need games in order to understand their daily lives, communicate with their environment and learn effectively. Because, playing is a learning tool for them. Games make it easier for children to think, fulfill their responsibilities, share and make decisions. Creative drama has emerged thanks to the games. The word drama refers to the improvisation of events in life. It is the portraying of a character, an event, a subject, a movement, emotion or thought (Arkkan, 2007). The word drama is known to be derived from the Greek word "dran". The word "dran" means "acting, role playing".

While creative drama is performed using theatrical methods or instant role playing, drama is the meaningful portraying of people's lives, thoughts, a certain event, education status as a team; and under some circumstances, it is the portraying of any abstract notions or behaviors on the condition of renewal and in the times when certain observations, experiences, thoughts and lives are controlled (San, 2002).

Creative drama is a group activity and cannot be performed without a group. In the drama event, the participants should be willing and ready for the event. It is very important for people to feel comfortable and safe. Creative drama makes use of the methods of theater. But it is not the same as theater. The most important feature of these methods is the improvisation of characters, objects or abstract concepts. In addition to improvisation and role playing in creative drama, different methods such as "story animation, imagination, envisioning, instructional games, etc." can be used. Individuals who take part in creative drama are called participants, and the person who directs them is called leader, instead of teacher. The participants, who are guided through the leader, improvise the events within the framework of the topic. A self-confident leader who knows what to do in a planned way accelerates the activity by ensuring the feelings, communication and vitality of the group members towards him/her and one another (Keyik, 2011).

The people who take part in creative drama prepare the environment for them to oscillate between real life and fictional life. All kinds of events, objects, concrete and abstract concepts can be animated. With these animations and the characters they take part in, children can come up with new syntheses in their lives and gain intellectual discipline. Since creative drama is a collective activity, it enables students to communicate with one another and to improve their skills of working together, bringing about teamwork to artistic activities. With creative drama, one can be more flexible and responsive to others, use the environment dynamically, and may be more sensitive to methods. He/she can also improve his/her creativity by enhancing abstract thinking skills (Keyik, 2011).

In the pre-school education processes, drama has become an important part of education as a field of art where learning is the foremost component. When the creative drama works in education are prepared for the acquisition of certain skills, the child will "pretend", and add symbolic understanding and expression richness to his/her natural skills (Adigüzel, 2011).

In the field of creative drama, one can judge, criticize, express him/herself easily without having any fear of guilt. The individual who programs different relationships, human behaviors and features in detail while presenting him/herself with various roles, also creates and develops new relationships and gains aesthetic and social experiences (San, 1991).

Drama teaches individuals to be sensitive, approve one another and share in accordance with their environment. Thus, individuals' confidence in themselves and others can develop. Because, self-confidence is not enough to succeed in social relations. It also entails to show tolerance and respect for the works of others, as well as being systematic and sharing. The student gains while performing the traits or as being a spectator (Akbaba et al. 2003).

Creative Drama education can have a significant impact on children. They can improve their thoughts and acquire the skills of instant decision making, can develop their imagination and capacity, improve their language and communication, learn to teamwork, and gain self-confidence.

Self-confidence emerges from the birth (even before the birth) of the individual and settles mainly in the early period. It may continue to develop rapidly until the age of 9-10. It is a phenomenon that develops with diminishing intensity during the life process. Children begin to understand and shape their self-confidence in adolescence. The most important factor affecting the formation and development of individual self-confidence in the early years is the family and the close environment. In the first years, children determine their status of self-confidence based on the feelings and thoughts that their parents make them feel . In addition to this, they might be affected by their close environment such as friends and teachers (Özbey, 2004). 
On the other hand, Bandura (1997) explains self-confidence as an individual's judgment of feeling worthy. Hambly (1997), defines self-confidence as the firm belief of the individual in his unique skills.

Self-confidence consists of two factors. These are 'feelings of being adequate and lovable'. When a school child is extremely timid, silent, shy, and dislikes being interested in, all of these symptoms indicate that the child doubts the feeling of being loved. If the child is reluctant to enter into a new challenge and is afraid of failure, and if s/he becomes upset when s/he does wrong, these symptoms are indicative of the child's suspicion of self-sufficiency (Humphreys, 2002).

A child with high self-confidence wants to get response, always expects attention from people. A child with low self-confidence, however, may turn down the interest he takes and dislikes being interested in because s/he does not get the response $\mathrm{s} / \mathrm{he}$ expects from people, $\mathrm{s} / \mathrm{he}$ is not interested in too much and is used to this situation.

Self-confidence is actually a person's trust in himself. A child who says "I can do it," "I believe I can do this", is a self-confident child.

Self-confidence is a concept that continues to evolve throughout human life. Children begin to shape and, consequently, evaluate their self-confidence from adolescence. Self-confidence, which is initially formed within the scope of the family's life style, develops with the school environment after the child starts school. Self-confidence is a phenomenon that varies across individuals. Some people have more dominant internal self-confidence whereas some have their external self-confidence more dominant. For example, if a child gets positive feedback for his achievements, yet, is exposed to criticism about his/her physical appearance, only one side of his/her self-confidence can develop and the other side remains latent (Özbey, 2004).

According to Varol (2007), self-sufficiency is the power of the individual to play the roles expected of him/her. As a matter of fact, Küçük (2011) defines self-sufficiency perception as "the person's own judgement on how to successfully perform and understand the activities necessary for him/her to achieve a certain performance".

Although the concepts of self-confidence and self-sufficiency are often confused, there is actually a difference between the two. Self-sufficiency is an assessment of one's abilities. Self-confidence, on the other hand, is the feeling of an existing ability (Say, 2005). That is, it is one's evaluating oneself. Self-sufficiency is defined as the level at which one is sufficient. The individual evaluates the level of his/her features to seek answers for him/her and questions his/her competence.

Play is whole thing for the children as an expression tool. Creative drama based on playing. Drama and self-confidence concepts are variables of this study. These variables were directly studied at primary and secondary level by Paylan (2013) and Çelik (2014). It generally was observed that creative drama education makes a positive impact on students' self-confidence development .The impact of creative drama education given to children is interested. What makes this study important and powerful is working on a preschool group.

\subsection{Objective}

The aim of this study is to observe the impact of musical creative drama education on self-confidence of 4-6 year-old preschool children. The questions to be answered for this purpose are as follows:

1) Is there a statistically significant difference in preschool students' levels of self confidence by gender, age (4-6 year-old) hometown, number of individuals living at the household, status of parents, number of siblings, child's birth order in the family, economic status of the family, age of starting school, caregivers before starting school, education level and occupation types of parents?

2) Is there a significant difference between the pre-test and post-test self-confidence scores of the students made by the teacher after the musical creative drama education given to preschool students?

3) Is there a significant difference between the pre-test and post-test self-confidence scores of the students made by the observer after the musical creative drama education given to preschool students?

4) Is there a significant difference between the pre-test and post-test self-confidence scores of the students made by the parents after the musical creative drama education given to preschool students?

\subsection{Hypothesis}

According to literature; creative drama education makes a positive impact on students' self-confidence development. The hypothesis of this study is to a significant difference between pre-school students' self-confidence and given creative drama education.

\subsection{Importance}

Although there are self-confidence studies on children, there are no studies on the self-confidence of preschool children. 
Music and drama can help 4-6 year-old children find their own self. The impact of creative drama education given to children is observed in this study.

\section{Method}

Qualitative and quantitative research methods were used together in this study. In this framework, qualitative observation method and quantitative experimental design were used together. The number of items in the self-confidence observation list used was 52. The scale score variance was calculated as 8.93 and total score variance as 8.94. Cronbach Alpha internal consistency coefficient, which is used to examine the internal consistency of the observation list prepared and set forth another reliability evidence, was calculated as 0.963 for boys and 0.857 for girls. An $\alpha$ score of 0.857 indicates high reliability according to the literature.

\subsection{Experimental Design}

The study was carried out in Tokat Private Ilgim Schools, with 4-6 tear-old preschool children in the 2018-2019 academic year. A total of 50 students, 9 students at the age of 4, 23 students at the age of 5 and 18 students at the age of 6 participated in the study. Second researcher collected children datas by observing and have the other datas by the forms answered parents and teachers.

\subsection{Data Collection Tools}

In the study, the Self-Confidence Observation Test developed by Günalp (2007) was completed in order to determine the self-confidence status of the students between the ages of 4-6 through making observations on the students by the author, class teacher and parents of the students before the musical drama education was started. In this way, the students' level of self-confidence before the application was determined. Then, for 10 weeks (between 12.11.2018 and 18.01.2019), these students were given musical drama education by their music teachers, the observer recorded his observations during the 10-week application period and then the self-confidence observation test was filled in again separately by the author, class teacher and parents as post-test. SPSS program was used for data analysis. "ANOVA" was used in the comparison of the levels of self confidence by hometown, number of individuals living at the household, status of parents, number of siblings, child's birth order in the family, economic status of the family, age of starting school, caregivers before starting school, education level and occupation types.

\section{Findings}

This section contains the findings related to the hypotheses of the study. Self-confidence scores were measured and evaluated before and after the musical creative drama exercises applied to the experiment group of preschool students.

\subsection{Findings Related to the Difference Between Pre-school Students' Self-confidence Levels by Gender}

Table 1. Comparison of self-confidence by gender

\begin{tabular}{lccccc}
\hline & $\mathrm{n}$ & Mean & Std. Deviation & $\mathrm{t}$ & $\mathrm{p}$ \\
\hline Boys & 29 & 95.5287 & 3.64334 & -.575 & \\
Girls & 21 & 96.0794 & 2.87500 & -.597 & .260
\end{tabular}

Table 3.1 shows the scores of the participant students according to the Self-Confidence Observation List. No significant relationship was found between gender and self-confidence according to the Table. Although girls' self-confidence was found to be higher than that of boys', this difference is not significant.

\subsection{Findings Related to the Difference Between Pre-school Students' Self-confidence Levels by Age}

Table 2. Comparison of Self-Confidence by Age Groups

\begin{tabular}{|c|c|c|c|c|c|c|c|c|c|}
\hline & \multirow[t]{2}{*}{$\mathrm{n}$} & \multirow[t]{2}{*}{ Mean } & \multirow{2}{*}{$\begin{array}{c}\text { Std. } \\
\text { Deviati } \\
\text { on }\end{array}$} & \multirow[t]{2}{*}{$\begin{array}{l}\text { Std. } \\
\text { Error }\end{array}$} & \multicolumn{2}{|c|}{$\begin{array}{l}\text { 95\% Confidence } \\
\text { Interval }\end{array}$} & \multirow{2}{*}{ Min. } & \multirow{2}{*}{ Max. } & \multirow{2}{*}{$\mathrm{p}$} \\
\hline & & & & & $\begin{array}{c}\text { Lower } \\
\text { Limit }\end{array}$ & $\begin{array}{l}\text { Upper } \\
\text { Limit }\end{array}$ & & & \\
\hline Single & 9 & 97.29 & 2.77 & .92537 & 95.1624 & 99.4302 & 93.33 & 101.00 & \\
\hline 2 Siblings & 23 & 94.31 & 3.41 & .71113 & 92.8441 & 95.7936 & 86.33 & 99.33 & 0.14 \\
\hline 3 Siblings & 18 & 96.83 & 2.80 & .66024 & 95.4404 & 98.2263 & 89.67 & 101.00 & \\
\hline Total & 50 & 95.76 & 3.32 & .46977 & 94.8160 & 96.7040 & 86.33 & 101.00 & \\
\hline
\end{tabular}

When the table is examined, students' mean self-confidence scores by their ages are as follows. The mean self-confidence score is 97.29 for 4-year-old students, 94.31 for 5-year-old students and 96.83 for 6-year-old students. 
4-year old students have the highest self-confidence levels. Significant difference has been found between 4 and 5 , and 5 and 6 year-olds. Therefore, a significant difference was found between the self confidence level by the age variable.

Table 3. Multiple Comparison of Self-Confidence by Ages

\begin{tabular}{ccccccc}
\hline & Age & $\begin{array}{c}\text { Mean } \\
\text { Difference }\end{array}$ & $\begin{array}{c}\text { Std. } \\
\text { Error }\end{array}$ & $\mathrm{p}$ & \multicolumn{2}{c}{\begin{tabular}{c} 
95\% Confidence Interval \\
\cline { 3 - 6 }
\end{tabular}} \\
& & & & $\begin{array}{c}\text { Lower } \\
\text { Limit }\end{array}$ & Upper Limit \\
\hline 4 Year-Old & 5 Year-Old & $2.97746^{*}$ & 1.21785 & .047 & .0301 & 5.9248 \\
& 6 Year-Old & .46296 & 1.26453 & .929 & -2.5974 & 3.5233 \\
\multirow{5}{*}{ 5 Year-old } & 4 Year-Old & $-2.97746^{*}$ & 1.21785 & .047 & -5.9248 & -.0301 \\
& 6 Year-Old & $-2.51449^{*}$ & .97476 & .034 & -4.8735 & -.1555 \\
& 4 Year-Old & -.46296 & 1.26453 & .929 & -3.5233 & 2.5974 \\
& 5 Year-Old & $2.51449^{*}$ & .97476 & .034 & .1555 & 4.8735 \\
\hline
\end{tabular}

3.3 Findings Related to the Differences in the Self-confidence Levels of Pre-school Students by Hometowns

Table 4. Comparison of the Levels of Self-Confidence by Hometowns

\begin{tabular}{|c|c|c|c|c|c|c|c|c|c|}
\hline & \multirow{3}{*}{$\mathrm{n}$} & \multirow{3}{*}{ Mean } & \multirow{3}{*}{$\begin{array}{c}\text { Std. } \\
\text { Deviatio } \\
\mathrm{n}\end{array}$} & \multirow{3}{*}{$\begin{array}{l}\text { Std. } \\
\text { Error }\end{array}$} & \multicolumn{2}{|c|}{ 95\% Confidence } & \multirow{3}{*}{ Min. } & \multirow{3}{*}{ Max. } & \multirow{3}{*}{$\mathrm{p}$} \\
\hline & & & & & & & & & \\
\hline & & & & & $\begin{array}{c}\text { Lower } \\
\text { Limit }\end{array}$ & $\begin{array}{l}\text { Upper } \\
\text { Limit }\end{array}$ & & & \\
\hline Tokat & 34 & 3.12022 & 2.77 & .53511 & 95.2839 & 97.4612 & 86.33 & 101.00 & \\
\hline Sivas & 5 & 3.75352 & 3.41 & 1.67862 & 89.8061 & 99.1273 & 90.33 & 99.00 & \\
\hline Resadiye & 3 & 5.01479 & 2.80 & 2.89529 & 81.9870 & 106.9019 & 89.67 & 99.67 & \\
\hline Amasya & 2 & .94281 & 3.32 & 66667 & 82.5292 & 99.4708 & 90.33 & 91.67 & \\
\hline Cankırı & 1 & & & & & & 95.33 & 95.33 & 0.346 \\
\hline Nigde & 1 & & & & & & 98.67 & 98.67 & \\
\hline Kayseri & 1 & & & & & & 97.67 & 97.67 & \\
\hline Mersin & 1 & & & & & & 93.33 & 93.33 & \\
\hline Zile & 1 & & & & & & 97.33 & 97.33 & \\
\hline Elazig & 1 & & & & & & 91.33 & 91.33 & \\
\hline Total & 50 & & 3.32178 & .46977 & 94.8160 & 96.7040 & 86.33 & 101.00 & \\
\hline
\end{tabular}

When the table is examined, no significant difference is seen in the self-confidence levels of students by their hometowns.

3.4 Findings Related to the Difference in the Levels of Preschool Students' Self-confidence by the Number of Individuals at the Household

Table 5. Comparison of Self-Confidence Levels by the number of individuals at the household

\begin{tabular}{|c|c|c|c|c|c|}
\hline $\begin{array}{l}\text { Individuals at } \\
\text { the household }\end{array}$ & $\mathrm{n}$ & Mean & Std. Deviation & $\mathrm{t}$ & $\mathrm{p}$ \\
\hline Nuclear & 47 & 96.1418 & 2.98041 & 3.585 & \\
\hline Family & 3 & 89.7778 & 2.98763 & 3.578 & 0.946 \\
\hline
\end{tabular}

No significant difference was seen in the levels of preschool students' self-confidence by the number of individuals living at the household. However, according to mean self-confidence scores, self confidences of children living in nuclear families are higher on average. 
3.5 Findings Related to the Difference in the Levels of Preschool Students' Self-confidence by Status of Parents

Table 6. Comparison of Self-Confidence Levels by Status of Parents

\begin{tabular}{cccccc}
\hline $\begin{array}{c}\text { Status of } \\
\text { Parents }\end{array}$ & $\mathrm{n}$ & Mean & Std. Deviation & $\mathrm{t}$ & $\mathrm{p}$ \\
\hline $\begin{array}{c}\text { Parents are } \\
\text { Alive and } \\
\text { Together }\end{array}$ & 49 & 95.6871 & 3.31551 & \\
& & & -1.089 & .282 \\
Parents are & 1 & 99.3333 & & \\
$\begin{array}{c}\text { Alive and } \\
\text { Separate }\end{array}$ & & & & \\
\hline
\end{tabular}

No significant difference was seen in the levels of preschool students' self-confidence by status of their parents.

3.6 Findings Related to the Difference in the Levels of Preschool Students' Self-confidence by Number of Siblings

Table 7. Comparison of Self-Confidence Levels by Number of Siblings

\begin{tabular}{cccccccccc}
\hline & $\mathrm{n}$ & Mean & $\begin{array}{c}\text { Std. } \\
\text { Deviation }\end{array}$ & $\begin{array}{c}\text { Std. } \\
\text { Error }\end{array}$ & $\begin{array}{c}95 \% \text { Confidence Interval } \\
\text { Lower } \\
\text { Limit }\end{array}$ & $\begin{array}{c}\text { Upper } \\
\text { Limit }\end{array}$ & Min. & Max. & $\mathrm{p}$ \\
\hline Single & 22 & 96.1667 & 3.01802 & .64344 & 94.8286 & 97.5048 & 91.00 & 101.00 & \\
2 Siblings & 17 & 95.5882 & 3.96605 & .96191 & 93.5491 & 97.6274 & 86.33 & 100.00 & .722 \\
3 Siblings & 11 & 95.2121 & 3.00471 & .90595 & 93.1935 & 97.2307 & 89.67 & 98.67 & \\
Total & 50 & 95.7600 & 3.32178 & .46977 & 94.8160 & 96.7040 & 86.33 & 101.00 & \\
\hline
\end{tabular}

When the table is examined, it is seen that single children have the highest self confidence-levels on average. No significant difference was found in the levels of preschool students' self-confidence by number of siblings.

3.7 Findings Related to the Difference in the Levels of Preschool Students' Self-confidence by the Child's Birth Order in the Family

Table 8. Comparison of Self-Confidence Levels by Birth Order

\begin{tabular}{|c|c|c|c|c|c|c|c|c|c|}
\hline & \multirow[t]{2}{*}{$\mathrm{n}$} & \multirow[t]{2}{*}{ Mean } & \multirow{2}{*}{$\begin{array}{c}\text { Std. } \\
\text { Deviation }\end{array}$} & \multirow{2}{*}{$\begin{array}{l}\text { Std. } \\
\text { Error }\end{array}$} & \multicolumn{2}{|c|}{$95 \%$ Confidence Interval } & \multirow[b]{2}{*}{ Min. } & \multirow[b]{2}{*}{ Max. } & \multirow[b]{2}{*}{$\mathrm{p}$} \\
\hline & & & & & $\begin{array}{c}\text { Lower } \\
\text { Limit }\end{array}$ & $\begin{array}{l}\text { Upper } \\
\text { Limit }\end{array}$ & & & \\
\hline Single & 34 & 95.8333 & 3.28372 & .56315 & 94.6876 & 96.9791 & 86.33 & 101.00 & \\
\hline 2nd child & 10 & 96.0333 & 3.41908 & 1.08121 & 93.5875 & 98.4792 & 88.67 & 100.00 & .787 \\
\hline 3rdChild & 6 & 94.8889 & 3.85093 & 1.57213 & 90.8476 & 98.9302 & 89.67 & 98.33 & \\
\hline Total & 50 & 95.7600 & 3.32178 & .46977 & 94.8160 & 96.7040 & 86.33 & 101.00 & \\
\hline
\end{tabular}

When Table 8 is examined, it seen that the 2nd-born children have the highest self-confidence while the 3rd- born children have the lowest. There is no significant difference between the levels of self-confidence by the birth order of children in the family.

3.8 Findings Related to the Difference in the Levels of Preschool Students' Self-confidence by Economic Status of Families

Table 9. Comparison of Self-Confidence Levels by Economic Status of the Family

\begin{tabular}{|c|c|c|c|c|c|c|c|c|c|}
\hline & \multirow[t]{2}{*}{$\mathrm{n}$} & \multirow[t]{2}{*}{ Mean } & \multirow{2}{*}{$\begin{array}{c}\text { Std. } \\
\text { Deviation }\end{array}$} & \multirow{2}{*}{$\begin{array}{l}\text { Std. } \\
\text { Error }\end{array}$} & \multicolumn{2}{|c|}{$95 \%$ Confidence Interval } & \multirow[b]{2}{*}{ Min. } & \multirow[b]{2}{*}{ Max. } & \multirow[b]{2}{*}{$\mathrm{p}$} \\
\hline & & & & & $\begin{array}{c}\text { Lower } \\
\text { Limit }\end{array}$ & $\begin{array}{l}\text { Upper } \\
\text { Limit }\end{array}$ & & & \\
\hline Low & 2 & 98.1667 & 1.17851 & .83333 & 87.5782 & 108.7552 & 97.33 & 99.00 & \\
\hline Medium & 37 & 95.4505 & 3.56095 & .58542 & 94.2632 & 96.6377 & 86.33 & 101.00 & \\
\hline High & 11 & 96.3636 & 2.52303 & .76072 & 94.6686 & 98.0586 & 90.33 & 99.00 & .429 \\
\hline Total & 50 & 95.7600 & 3.32178 & .46977 & 94.8160 & 96.7040 & 86.33 & 101.00 & \\
\hline
\end{tabular}

Economic status of preschool students is as follows: The average self-confidence scores of children coming from low-income families is 98.16 , from middle-income families is 95.45 , and from high-income families is 96.36 . There is no significant difference between preschool students' levels of self-confidence by the economic status of their families. 
3.9 Findings Related to the Difference Between the Self-confidence Levels of Preschool Students by Their Mothers' Level of Education

Table 10. Comparison of Self-Confidence Levels by Education Levels of the Mother

\begin{tabular}{|c|c|c|c|c|c|c|c|c|c|}
\hline & \multirow[t]{2}{*}{$\mathrm{n}$} & \multirow[t]{2}{*}{ Mean } & \multirow{2}{*}{$\begin{array}{c}\text { Std. } \\
\text { Deviation }\end{array}$} & \multirow{2}{*}{$\begin{array}{l}\text { Std. } \\
\text { Error }\end{array}$} & \multicolumn{2}{|c|}{ 95\% Confidence Interval } & \multirow[b]{2}{*}{ Min. } & \multirow[b]{2}{*}{ Max. } & \multirow[b]{2}{*}{$\mathrm{p}$} \\
\hline & & & & & $\begin{array}{l}\text { Lower } \\
\text { Limit }\end{array}$ & $\begin{array}{l}\text { Upper } \\
\text { Limit }\end{array}$ & & & \\
\hline Primary School & 1 & 97.3333 & & & & & 97.33 & 97.33 & \\
\hline Secondary school & 2 & 92.8333 & 2.59272 & 1.83333 & 69.5386 & 116.1280 & 91.00 & 94.67 & \\
\hline High school & 7 & 94.0952 & 4.89412 & 1.84980 & 89.5689 & 98.6215 & 86.33 & 99.33 & .254 \\
\hline University & 40 & 96.1583 & 2.97376 & .47019 & 95.2073 & 97.1094 & 88.67 & 101.00 & \\
\hline Total & 50 & 95.7600 & 3.32178 & .46977 & 94.8160 & 96.7040 & 86.33 & 101.00 & \\
\hline
\end{tabular}

When the table is examined, the mean self confidence scores of children whose mothers are primary school graduate is 97.33, are secondary school graduate is 92.83 , are high school graduate is 94,09 , and are university graduate is 96.15 . The highest average belongs to children whose mothers are primary school graduates. However, no significant difference was found between preschool students' levels of the self-confidence by their mothers' level of education

3.10 Findings Related to the Difference in the Levels of Preschool Students' Self-confidence by Their Fathers' Level of Education

Table 11. Comparison of Self-confidence Levels by Father's Education Levels

\begin{tabular}{lccccccccc}
\hline & $\mathrm{n}$ & Mean & $\begin{array}{c}\text { Std. } \\
\text { Deviation }\end{array}$ & $\begin{array}{c}\text { Std. } \\
\text { Error }\end{array}$ & $\begin{array}{c}\text { 95\% Confidence Interval } \\
\text { Lower } \\
\text { Limit }\end{array}$ & $\begin{array}{c}\text { Upper } \\
\text { Limit }\end{array}$ & Min. & Max. & $p$ \\
\hline Secondary School & 1 & 91.0000 & & & & & & 91.00 & 91.00 \\
High school & 10 & 94.2667 & 4.92863 & 1.55857 & 90.7409 & 97.7924 & 86.33 & 101.00 \\
University & 39 & 96.2650 & & .42457 & 95.4055 & 97.1245 & 90.33 & 101.00 & .081 \\
Total & 50 & 95.7600 & 2.65147 & .46977 & 94.8160 & 96.7040 & 86.33 & 101.00 \\
& & & 3.32178 & & & & & &
\end{tabular}

When the table is examined, the average self-confidence scores of students whose fathers are secondary school graduate is 91.00 , are high school graduates is 94.26 , and are university graduates is 96.26 . The highest average belongs to children whose fathers are university graduate. However, no significant difference was found between preschool students' levels of the self-confidence by their fathers' education level. 
3.11 Findings Related to the Difference in the Levels of Preschool Students' Self-confidence by Their Mother's Occupation

Table 12. Comparison of Self-confidence Levels by Mother's Occupation

\begin{tabular}{|c|c|c|c|c|c|c|c|c|c|}
\hline \multirow[t]{3}{*}{ Occupations } & \multirow[t]{3}{*}{$\mathrm{n}$} & \multirow[t]{3}{*}{ Mean } & \multirow[t]{3}{*}{$\begin{array}{c}\text { Std. } \\
\text { Deviation }\end{array}$} & \multirow[t]{3}{*}{$\begin{array}{l}\text { Std. } \\
\text { Error }\end{array}$} & \multicolumn{2}{|c|}{$\begin{array}{l}95 \% \text { Confidence } \\
\text { Interval }\end{array}$} & \multirow[t]{3}{*}{ Min. } & \multirow[t]{3}{*}{ Max. } & \multirow{3}{*}{$\mathrm{p}$} \\
\hline & & & & & Lower & Upper & & & \\
\hline & & & & & Limit & Limit & & & \\
\hline Teacher & 14 & 96.7857 & 2.46898 & .65986 & 95.3602 & 98.2113 & 91.67 & 101.00 & \\
\hline Doctor & 3 & 96.0000 & 4.91031 & 2.834997 & 83.8021 & 108.1979 & 90.33 & 99.00 & \\
\hline Nurse & 2 & 97.3333 & .00000 & .00000 & 97.3333 & 97.3333 & 97.33 & 97.33 & \\
\hline Housewife & 14 & 94.7143 & 4.29641 & 1.14826 & 92.2336 & 97.1950 & 86.33 & 101.00 & \\
\hline Civil Servant & 3 & 97.1111 & 2.71484 & 1.56742 & 90.3671 & 103.8552 & 94.00 & 99.00 & .689 \\
\hline Lawyer & 1 & 94.0000 & & & & & 94.00 & 94.00 & \\
\hline Architect & 1 & 98.6667 & & & & & 98.67 & 98.67 & \\
\hline Engineer & 3 & 95.1111 & 1.01835 & .58794 & 92.5814 & 97.6408 & 94.00 & 96.00 & \\
\hline Police & 1 & 91.3333 & & & & & 91.33 & 91.33 & \\
\hline Tradesman & 2 & 94.6667 & 4.24264 & .00000 & 56.5481 & 132.7853 & 91.67 & 97.67 & \\
\hline Psychologist & 1 & 93.3333 & & & & & 93.33 & 93.33 & \\
\hline Physiotherap & 1 & 97.3333 & & & & & 97.33 & 97.33 & \\
\hline ist & 1 & 100.0000 & & & & & 100.00 & 100.00 & \\
\hline $\begin{array}{l}\text { Urban } \\
\text { Planner }\end{array}$ & 1 & 95.0000 & & & & & 95.00 & 95.00 & \\
\hline $\begin{array}{l}\text { Lab } \\
\text { Technician }\end{array}$ & 1 & 98.3333 & & & & & 98.33 & 98.33 & \\
\hline $\begin{array}{l}\text { Medical } \\
\text { Secretariat }\end{array}$ & 1 & 90.3333 & & & & & 90.33 & 90.33 & \\
\hline Faculty & 50 & 95.7600 & 3.32178 & .46977 & 94.8160 & 96.7040 & 86.33 & 101.00 & \\
\hline
\end{tabular}

When the table is examined, the occupation with the highest average is architect and the profession with the lowest average is police. No significant difference was found between the self-confidence levels of preschool students by their mother's occupation. 
3.12 Findings Related to the Difference in the Levels of Preschool Students' Self-confidence by Their Father's Occupation

Table 13. Comparison of self-confidence Levels by Father's Occupation

\begin{tabular}{|c|c|c|c|c|c|c|c|c|c|}
\hline \multirow[t]{2}{*}{ Occupations } & \multirow[t]{2}{*}{$\mathrm{n}$} & \multirow[t]{2}{*}{ Mean } & \multirow{2}{*}{$\begin{array}{c}\text { Std. } \\
\text { Deviatio } \\
\mathrm{n}\end{array}$} & \multirow[t]{2}{*}{$\begin{array}{l}\text { Std. } \\
\text { Error }\end{array}$} & \multicolumn{2}{|c|}{$\begin{array}{l}\text { 95\% Confidence } \\
\text { Interval }\end{array}$} & \multirow{2}{*}{ Min. } & \multirow{2}{*}{ Max. } & \multirow{2}{*}{$\mathrm{p}$} \\
\hline & & & & & $\begin{array}{l}\text { Lower } \\
\text { Limit }\end{array}$ & $\begin{array}{l}\text { Upper } \\
\text { Limit }\end{array}$ & & & \\
\hline Teacher & 11 & 96.4848 & 2.34456 & .70691 & 94.9098 & 98.0599 & 91.67 & 99.33 & \\
\hline Doctor & 5 & 96.0667 & 3.52294 & 1.57551 & 91.6924 & 100.4410 & 90.33 & 99.00 & \\
\hline Self-employed & 5 & 96.0667 & 5.02438 & 2.24697 & 89.8281 & 102.3053 & 90.33 & 101.00 & \\
\hline Manager & 1 & 94.6667 & & & & & 94.67 & 94.67 & \\
\hline Civil Servant & 3 & 96.3333 & 2.02759 & 1.17063 & 91.2965 & 101.3701 & 94.00 & 97.67 & .223 \\
\hline $\begin{array}{l}\text { Traffic } \\
\text { Insurance }\end{array}$ & 1 & 89.6667 & & & & & 89.67 & 89.67 & \\
\hline & 2 & 98.0000 & .94281 & .66667 & 89.5292 & 106.4708 & 97.33 & 98.67 & \\
\hline $\mathrm{MI}$ & 8 & 97.0833 & 2.28000 & .80610 & 95.1772 & 98.9895 & 94.00 & 100.00 & \\
\hline & 3 & 93.7778 & 2.14303 & 1.23728 & 88.4542 & 99.1014 & 91.33 & 95.33 & \\
\hline Trades & 7 & 94.0952 & 4.11733 & 1.55620 & 90.2873 & 97.9031 & 86.33 & 97.67 & \\
\hline Academician & 1 & 98.6667 & & & & & 98.67 & 98.67 & \\
\hline $\begin{array}{l}\text { Deputy } \\
\text { Director }\end{array}$ & 1 & 99.3333 & & & & & 99.33 & 99.33 & \\
\hline $\begin{array}{l}\text { Program } \\
\text { Operator }\end{array}$ & 1 & 88.6667 & & & & & 88.67 & 88.67 & \\
\hline Faculty & 1 & 93.3333 & & & & & 93.33 & 93.33 & \\
\hline Total & 50 & 95.7600 & 3.32178 & .46977 & 94.8160 & 96.7040 & 86.33 & 101.00 & \\
\hline
\end{tabular}

When the table is examined, it is seen that the highest average occupation belongs to deputy director and the lowest average occupation belongs to faculty member. No significant difference was found between the self-confidence levels of preschool students by their father's occupation.

3.13 Findings Related to the Difference Between Pre-school Students' Self-confidence Levels by Age of Starting School Table 14. Comparison of Self-confidence Levels by the Children's Age of Starting School

\begin{tabular}{ccccccccccc}
\hline Ages & $\mathrm{n}$ & Mean & $\begin{array}{c}\text { Std. } \\
\text { Deviation }\end{array}$ & $\begin{array}{c}\text { Std. } \\
\text { Error }\end{array}$ & $\begin{array}{c}\text { 95\% Confidence Interval } \\
\text { Lower } \\
\text { Limit }\end{array}$ & $\begin{array}{c}\text { Upper } \\
\text { Limit }\end{array}$ & Min. & Max. & $\mathrm{p}$ \\
\hline 2 year-old & 6 & 96.0556 & 1.69203 & .69077 & 94.2799 & 97.8312 & 94.00 & 98.67 & \\
3 year-old & 12 & 95.7778 & 3.48832 & 1.00699 & 93.5614 & 97.9941 & 90.33 & 101.00 & .441 \\
4 Year-Old & 22 & 94.9394 & 3.93685 & .83934 & 93.1939 & 96.6849 & 86.33 & 99.33 & \\
5 Year-old & 7 & 97.1429 & 1.98939 & .75192 & 95.3030 & 98.9827 & 94.00 & 99.67 & \\
6 Year-old & 3 & 97.8889 & .69389 & .40062 & 96.1652 & 99.6126 & 97.33 & 98.67 & \\
Total & 50 & 95.7600 & 3.32178 & .46977 & 94.8160 & 96.7040 & 86.33 & 101.00
\end{tabular}

When the table is examined, it is seen that the highest average belongs to children who started school at the age of 6 and the lowest belongs to those who started school at the age of 4 . No significant difference was found between pre-school students' self-confidence levels by the age of starting school. 
3.14 Findings Related to the Difference Between Preschool Students' Levels of Self-confidence by Their Caregivers Before Starting School

Table 15. Comparison of Self-confidence Levels by Caregivers Before Starting School

\begin{tabular}{|c|c|c|c|c|c|c|c|c|c|}
\hline \multirow[t]{2}{*}{ Caregivers } & \multirow[t]{2}{*}{$\mathrm{n}$} & \multirow[t]{2}{*}{ Mean } & \multirow{2}{*}{$\begin{array}{c}\text { Std. } \\
\text { Deviatio } \\
\mathrm{n}\end{array}$} & \multirow[t]{2}{*}{$\begin{array}{l}\text { Std. } \\
\text { Error }\end{array}$} & \multicolumn{2}{|c|}{$\begin{array}{l}\text { 95\% Confidence } \\
\text { Interval }\end{array}$} & \multirow{2}{*}{ Min. } & \multirow{2}{*}{ Max. } & \multirow{2}{*}{$\mathrm{p}$} \\
\hline & & & & & $\begin{array}{c}\text { Lower } \\
\text { Limit }\end{array}$ & $\begin{array}{l}\text { Upper } \\
\text { Limit }\end{array}$ & & & \\
\hline Caregiver & 16 & 96.2083 & 2.76452 & .69113 & 94.7352 & 97.6714 & 90.33 & 99.33 & \\
\hline Mother & 15 & 95.4889 & 3.47523 & .89730 & 93.5644 & 97.4134 & 88.67 & 101.00 & \\
\hline Mother and Father & 4 & 96.1667 & 2.20269 & 1.10135 & 92.6617 & 99.6716 & 94.00 & 98.67 & \\
\hline $\begin{array}{l}\text { Grandmother } \\
\text { (Mom's) }\end{array}$ & 8 & 95.2083 & 3.43159 & 1.21325 & 92.3395 & 98.0772 & 90.33 & 100.00 & .073 \\
\hline Grandmother (Dad's) & 3 & 95.4444 & 3.28859 & 1.89867 & 87.2751 & 103.6138 & 91.67 & 97.67 & \\
\hline $\begin{array}{l}\text { Grandmother } \\
\text { (Mom's) and } \\
\text { Grandmother (Dad's) }\end{array}$ & 2 & 100.1667 & 1.17851 & .83333 & 89.5782 & 110.7552 & 99.33 & 101.00 & \\
\hline $\begin{array}{lr}\text { Caregiver and } \\
\text { Grandmother (Dad's) }\end{array}$ & 1 & 97.0000 & & & & & 97.00 & 97.00 & \\
\hline $\begin{array}{l}\text { Mother and } \\
\text { Grandmother (Dad's) }\end{array}$ & 1 & 86.3333 & & & & & 86.33 & 86.33 & \\
\hline Total & 50 & 95.7600 & 3.32178 & .46977 & 94.8160 & 96.7040 & 86.33 & 101.00 & \\
\hline
\end{tabular}

When the table is examined, it is seen that the highest self-confidence average (100.16) belongs to children given care by their both grandmothers, whereas the lowest self-confidence average (86.33) belongs to children given care by their mother and grandmother. However, this difference is not significant.

3.15 Findings Related to the Differences Between the Pretest, Posttest and Self-confidence Scores Made by the Teacher, Author and Parents After the Musical Drama Educations Given to the Students

Table 16. Comparison of the Pretest and Posttest Self Confidence Scores Given by Teachers, Parents and the Author

\begin{tabular}{cccccc}
\hline & $\mathrm{n}$ & Mean & $\begin{array}{c}\text { Std. } \\
\text { Deviation }\end{array}$ & $\mathrm{t}$ & $\mathrm{p}$ \\
\hline Teacher's Pretest Scoring & 50 & 93.7800 & 5.77571 & -.683 & .498 \\
Teacher's Posttest Scoring & 50 & 94.4000 & 6.91641 & & \\
Parent's Pretest Scoring & 50 & 91.5600 & 6.36046 & -1.963 & .055 \\
Parent's Posttest Scoring & 50 & 93.6600 & 5.81907 & & \\
Author's Pretest Scoring & 50 & 90.1800 & 5.74168 & -12.028 & .000 \\
Author's Posttest Scoring & 50 & 99.2200 & 2.11206 & &
\end{tabular}

Table shows that the difference between the pretests and posttests filled in by the teacher and parents are not significant. Only significant difference was found between the pretest and posttest scores given by the author. 


\subsection{Pertest-Posttest Averages}

Table 17. Average Pretest-Posttest Self-Confidence Scores

\begin{tabular}{rcccc}
\hline & $\mathrm{n}$ & Mean & Std. Deviation & Std. Error \\
\hline Pretest & 50 & 91.8400 & 5.16979 & .73112 \\
Posttest & 50 & 95.7600 & 3.32178 & .46977
\end{tabular}

According to the average scores, self-confidence pretest score is 91.84 while the posttest score is 95.76. An increase has been found in the self-confidence levels of children. The difference between average pretest and posttest scores is statistically significant.

Table 18. Average Pretest-Posttest Self-Confidence Scores

\begin{tabular}{|c|c|c|c|c|c|c|c|}
\hline & \multirow[t]{2}{*}{ Mean } & \multirow[t]{2}{*}{$\begin{array}{c}\text { Std. } \\
\text { Deviation }\end{array}$} & \multirow[t]{2}{*}{$\begin{array}{l}\text { Std. } \\
\text { Error }\end{array}$} & \multicolumn{2}{|c|}{$\begin{array}{l}95 \% \text { Confidence } \\
\text { Interval }\end{array}$} & \multirow{2}{*}{$\mathrm{t}$} & \multirow{2}{*}{$\mathrm{p}$} \\
\hline & & & & $\begin{array}{l}\text { Lower } \\
\text { Limit }\end{array}$ & $\begin{array}{l}\text { Upper } \\
\text { Limit }\end{array}$ & & \\
\hline $\begin{array}{l}\text { Average Pretest } \\
\text { Posttest Scores }\end{array}$ & -3.92000 & 3.89753 & .55119 & -5.02767 & -2.81233 & -7.112 & .000 \\
\hline
\end{tabular}

\section{Conclusions and Discussion}

No significant difference was found between the self-confidence scores of male and female preschool students based on the gender variable. Although the average self-confidence scores of girl students are higher than that of boys, the difference is not statistically significant. A significant difference was found between the self confidence scores of preschool students by the age variable. While the highest average self-confidence was seen in 4 year-old students, 5 year-old students showed the lowest self-confidence level. That is, no such definition as the youngest child has the highest self-confidence can be made. There are significant differences between 4 and 5 year-old children, and 5 and 6 year-olds. There are 10 provinces under the hometown variable. No significant difference was seen in the self-confidence levels of students by their hometowns. It was seen that students whose hometown is Nigde have the highest self-confidence. The two students whose hometown is Amasya demonstrated the lowest self-confidence levels. The number of people living in the household variable has two categories. Students who have nuclear families have higher self-confidence scores on average than those who have large family structures. Nonetheless, the difference between these two family types is not significant. Another question whose answer was sought in the study was whether whether the parents are living together has any impact on self-confidence Parents of 49 students in the sample group were reported to be alive and living together, while parents of 1 child was alive, but broken up. Results show that the student whose parents are broken up has the highest self confidence score with 99.33. No significant difference was found in the self-confidence levels of students by their parents' status and it did not make any positive impact. No significant difference was found in the self-confidence levels of students by the number of siblings variable. Single children have higher self-confidence. No significant difference was found in the self-confidence levels of students by their birth order. However, 2nd born children have the highest self-confidence while 3rd born children have the lowest. No significant difference was found in the self-confidence levels of students by economic status of the families. The highest average self-confidence scores was found in students from low-income families. The lowest average self-confidence scores, on the other hand, was found in students from middle-income families. No significant difference was found in the self-confidence levels of students by their mother's education status. Only one out of 50 students in the sample has a primary school graduate mother, and this student has the highest self-confidence score. The remaining confidence scores by mother's education status belong to the children of secondary school graduate moms, high school graduate moms and university graduate moms from lower to higher. No significant difference was found in the self-confidence levels of students by their father's education status. Children whose fathers are university graduate seem to have the highest self confidence scores on average while those whose fathers are secondary school graduates have the lowest. No significant difference was found in the self-confidence levels of students by their mother's occupation. The occupation with highest average score is architect while the lowest is police. No significant difference was found in the self-confidence levels of students by their father's occupation. The occupation with highest average score is deputy manager while the lowest is faculty. No significant difference was found in the self-confidence levels of students by the age of starting school. Students who started school at the age of 6 have the highest average self-confidence score. The lowest score was found in those who started school at the age of 4 . 
No significant difference was found in the self-confidence levels of students by the caregivers before starting school. The differences between the pretests and posttests completed by the teacher and parents after the musical drama education given to preschool students was not statistically significant. The difference between the pretest and posttest scores of self-confidence applied by the author was significant. According to the results obtained from the study, a significant difference was observed in the self-confidence of the students after they take musical drama education. It has been observed that musical drama education positively affects the sense of self-confidence. During the 10-week study period, it was observed that the students improved their self-expression and communication with their friends.

In this study, it was seen that musical creative drama education makes a positive impact on children's self-confidence. The extant literature has been reviewed since there exists a research portfolio in this area. In Çelik's thesis (2014), entitled "Ortaokul öğrencilerinin özgüven düzeyinin bazı değişkenler açısından değerlendirilmesi” [Evaluation of secondary school students' self-confidence level in terms of some variables], no significant difference was found in self-confidence levels of male and female students. By the same token, there was no significant difference in terms of family type, parents' status, birth order and number of siblings. However, significant differences were found in terms of place of residence, economic level and educational status of parents. When secondary school students and preschool students are compared, it can be seen that there is no significant difference in self-confidence levels of students with respect to gender, family type, parents' status, birth order and number of siblings in both studies. No significant difference was seen in terms of place of residence, economic status of family, age of starting school, the caregiver before starting school, occupations and education levels of the parents of the preschool students. In the thesis study by Paylan (2013) entitled "İlkokulda yapılan yaratıcı drama etkinliklerinin öğrencilerin özgüven gelişimine etkisi” [Impact of creative drama activities in the primary school on the students' self-confidence development], it was observed that creative drama education makes a positive impact on students' self-confidence development. A similar positive improvement has been observed in the behaviors of preschool students after the creative drama education. It has been found that revealing their creativity when they are being educated enhances the self-confidence of children. It was observed that after the musical creative drama education, children with some aggressive behaviors reduced such behaviors.

In traditional education systems, applications such as rote learning and textbook dependence may cause students to lose their creativity. Learning and teaching environments should be organized in a way to reveal the creativity of the student. It is recommended that music teachers prepare course plans by combining music and creative drama and actively implementing them, to ensure a permanent learning on children and to render them continuous learners.

\section{References}

Adıgüzel, Ö. (2011). Introduction to Pre-school drama. Anadolu University Publications.

Akbaba, S., Sağlam, S., \& Kök, M. (2003). Drama and games in education and training. Erzurum: Cemre Publisher.

Arıkan, Y. (2007). Pratical drama and drama education for primary schools. İstanbul: Pozitif Publisher.

Bandura, A. (1997). Self-efficacy: The exercise of control. New York: Freeman.

Bayram, E., Özgül, E., Kaplan, G., Ünal, H. A., Yapagili, H., \& Demir, K. (1999). Primary schools Drama 1, Ankara: MEB Publisher.

Çelik, İ. (2014). Evaluation of secondary school students' self-confidence levels in terms of some variables (Afyonkarahisar case) (Published Master's Thesis). Turkish Aeronautical Association University, Social Sciences Institute, Ankara.

Becker, D. R., McClelland, M.M., Loprinzi, P., \& Trost, S. G. (2014). Physical Activity, Self-Regulation, and Early Academic Achievement in Preschool Children, Early Education and Development, 25(1), 56-70. https://doi.org/10.1080/10409289.2013.780505

Günalp, A. (2007). The effect of different parental attitudes on the development of self-confidence in preschool children (Aksaray case) (Unpublished Master's Thesis). Selcuk University Social Sciences Institute, Konya.

Güryl1, E. (2011). Examination of the effects of rhythmic movements on coordination development of children aged 6 years (Published Master's Thesis). Marmara University Educational Sciences Institute, Istanbul.

Hambly, K. (1997). Self-Confidence. (B. Biçakçı, Trans.). İstanbul: Rota.

Humphreys, T. (2002). The key to child education: self-confidence. Translated by: Anapa, T. İstanbul: Epsilon Publisher.

Keyik S. (2011). Creative drama activities in art education classes (Published Master's Thesis). Selcuk University Social Sciences Institute, Konya.

Koçyiğit, S., Tuğluk, M., \& Kök, M. (2010). Play as an educational activity in the child's development process. Atatürk 
University Journal of Kazlm Karabekir Education Faculty, O(16), 324-342.

Özbey, Ç. (2004). Constructive solutions to child problems. İstanbul: Ink1lap Publisher.

Paylan, N. (2013). The effect of creative drama activities on primary school students' self-confidence, (Published Master's Thesis). Atatürk University Educational Sciences Institute, Erzurum.

San, İ, (1991). Educational drama creative dimensions, Dokuz Eylül University, Buca Education Faculty 1. İzmir Education Congress, İzmir.

San, İ. (2002). Creative Drama Educational- Dimensions. creative drama 1985-1995 posts, (Edit. Adıüzel, H.Ö). Ankara: Naturel.

Say, A. (2005). Music dictionary. Ankara: Music Encyclopedia Publisher.

Sütçï Z. (2006). Analysis of the effect of drama education on the nutritional habits of six-year-old children attending preschool education (Published master's thesis). Selcuk University Social Sciences Institute, Konya.

Varol, B. (2007). Self-efficacy of physical education and sports teaching students about teaching profession (Master's thesis). Ömer Halis Demir University Educational Sciences Institute, Niğde.

Yörükoğlu, A. (1986). Age of youth: mental health and mental problems. Ankara: Turkey Isbank Cultural Publications.

\section{Copyrights}

Copyright for this article is retained by the author(s), with first publication rights granted to the journal.

This is an open-access article distributed under the terms and conditions of the Creative Commons Attribution license which permits unrestricted use, distribution, and reproduction in any medium, provided the original work is properly cited. 